\title{
Transformasi Dompet Dhuafa dari Lembaga Amil Zakat menjadi Lembaga Sosial- Kemanusiaan
}

\begin{abstract}
Ali Nurdin
Abstrak

Tulisan ini mengulas sejarah perkembangan Dompet Dhuafa dari Lembaga Amil Zakat(LAZ) menjadi Lembaga sosial-kemanusiaan. Penulis berasumsi, bahwa Dompet Dhuafa bertransformasi dari Lembaga Amil Zakat dan berkembang menjadi Lembaga Sosial-Kemanusiaan. Dompet Dhuafa berbeda dengan LAZ yang lain karena memiliki program sosial-kemanusiaan. Pembahasan tulisan ini langsung tertuju pada periode sosial-kemanusiaan Dompet Dhuafa (2004-2012) dan selanjutnya analisis transformasi Dompet Dhuafa.

Fenomena perkembangan lembaga filantropi Islam di Indonesia, kini telah berkembang dengan cukup baik. Dompet Dhuafa merupakan salah satu lembaga filantropi Islam Indonesia yang terbilang cukup sukses, dimana lembaga ini menggunakan manajemen modern. Dompet Dhuafa berkembang seiring berjalan waktu dan pergantian kepemerintahan Orde Baru menuju era Reformasi, perubahan kekuasaan banyak mendapat pengaruh positif dari munculnya Reformasi tersebut. Transformasi program karena bukan hanya sebagai lembaga yang bertugas mengurus penghimpunan zakat saja tetapi sosial-kemanusiaan pun telah dijalankannya menjadi program lembaga.

Penelitian ini mengkaji dan mengungkapkan perkembangan transformasi Dompet Dhuafa. Adapun tulisan ini merupakan sejarah kontemporer. Metode penelitian yang digunakan adalah metode historis dan lebih bersifat deskriptif- Analitis terhadap gambaran dan penguraian sejarah perkembangan Dompet Dhuafa.
\end{abstract}

\begin{abstract}
This paper reviews the historical development of the Amil of Dompet Dhuafa Zakat (LAZ) became social-humanitarian Agencies. The authors assume, that transformed the institution of Dompet Dhuafa Amil Zakat and developed into a Social-Humanitarian Agencies. Dompet Dhuafa is different to the others because it has a LAZ social program-humanity. Discussion this paper is directly fixed on the social-humanitarian period of Dompet Dhuafa (2004-2012) and the subsequent analysis of the transformation of Dompet Dhuafa. The phenomenon of the development of Islamic philanthropic institutions in Indonesia, has now grown quite well. Dompet Dhuafa is one of the Indonesia Islamic philanthropic institutions is quite successful, where the Agency is using modern management. Dompet Dhuafa grow as time goes on and the turn toward the new order era of National Reform, the change of power gets a positive influence of the rise of the Reformation. The transformation of the program because not just an institution collecting zakat but also social humanity program.

This reseach found the development of Dompet Dhuafa in contemporer side. This using historical dan descriptive analysis method to the development of it history.
\end{abstract}

Kata Kunci : Filantropi Islam, Dompet Dhuafa, Lembaga Sosial Kemanusiaan 


\section{A. Pendahuluan}

\section{Latar Belakang Masalah}

Fenomena yang sangat membanggakan memang, bahwa filantropi Islam di Indonesia sekarang tengah mengalami perkembangan yang cukup signifikan, paling tidak dalam dekade-dekade belakangan ini. ${ }^{1}$ Berkembangnya filantropi Islam di Indonesia ini, merupakan suatu fenomena positif bagi umat Islam khususnya, dan rakyat Indonesia pada umumnya. Perkembangan ini sangat penting tentunya bagi masyarakat Indonesia karena kini tengah terjadi di tengah perubahan sosial-politik menuju tatanan baru yang demokratis. ${ }^{2}$

Bila melihat tradisi masa lalu yakni mengenai filantropi Islam di Indonesia, tradisi tersebut berkembang dalam waktu yang lama dan sangat panjang, hal ini seiring dengan adanya proses penyebaran Islam di Nusantara yang berlangsung secara bertahap. Berawal dari masuknya periode-periode awal masuknya Islam, filantropi Islam tumbuh dan lambat laun mulai rata dijalankan pada abad ke-19 ketika Islam sudah mulai menjadi agama mayoritas di Nusantara. ${ }^{3}$

$\begin{array}{ccc}\text { Praktek filantropi } & \text { Islam } \\ \text { cukup membawa perubahan } & \text { yang }\end{array}$ besar pada masyarakat Nusantara. Filantropi Islam berkembang sejalan dengan masuknya Islam dan

${ }^{1}$ Irfan Abubakar dan Chaider S. Bamualim, ed., Filantropi Islam dan Keadilan Sosial Studi tentang Potensi, Tradisi, dan pemanfaatan Filantropi Islam di Indonesia, (Jakarta : CSRC UIN Jakarta, 2006), h. xiii

2 Murni Djamal, "Kata Pengantar" lihat dalam Irfan Abubakar dan Chaider S. Bamualim, ed., Revitalisasi Filantropi Islam Studi Kasus Lembaga Zakat dan Wakaf Di Indonesia, (Jakarta:Pusat Bahasa dan Budaya UIN Jakarta, 2005), h.v

${ }^{3}$ Bakar dan Bamualim, ed., Filantropi Islam dan Keadilan Sosial, h. 95 perkembangan Islam di Nusantara, praktek filantropi Islam ini mengalami transformasi dari tradisonal menjadi modern. Proses perkembangan filantropi Islam tersebut terjadi secara berangsurangsur dan bertahap. ${ }^{4}$ Begitulah sebuah perjalanan sejarah filantropi Indonesia yang memiliki perkembangan cukup panjang berawal dari kedatangan Islam di Nusantara. Masa Orde Baru merupakan kondisi sosial-politik yang cukup baik, sehingga banyak melahirkan Lembaga Amil Zakat (LAZ) dan Badan Amil Zakat (BAZ) milik pemerintah. Beberapa Lembaga Amil Zakat swasta banyak berdiri sebagai yayasan salah satunya adalah Dompet Dhuafa Republika. Yayasan filantropi tersebut berkembang menjadi Lembaga Amil Zakat tingkat nasional dan menjadi motor penggerak filantropi Islam pada masa Reformasi. ${ }^{5}$

Perkembangan lembaga filantropi yang mantap dengan sendirinya akan dapat mendukung perwujudan masyarakat sipil yang kuat, mandiri dan sejahtera. sementara dalam pencapaiannnya sendiri akan memberikan arti dan juga memenuhi kebutuhan yang sangat penting bagi sebuah perubahan di era Reformasi, demokratisasi dan transformasi sosial di Indonesia.

Dompet Dhuafa Republika (selanjutnya disebut DD) dilahirkan

${ }^{4}$ Amelia Fauzia, Faith and The state : A History Of Islamic Philantrophy in Indonesia, (Leiden,The Netherlands : Koninklijke Brill NV, 2013). Pembahasan terdiri dari bagian I filantropi awal kedatangan Islam, bagian kedua filantropi Islam di bawah masa kolonial, dan ketiga perkembangan filantropi Islam setelah Indonesia merdeka. Selanjutnya penjelasan lihat bagian II, bab 1 membahas mengenai filantropi Islam pada masa periode kolonial, dan bagian III, bab 1 filantropi Islam setelah Indonesia merdeka.

5 Djamal, "Kata Pengantar" dalam Bakar dan Bamualim, ed., Revitalisasi Filantropi Islam, h.v 
pada 2 Juli 1993 dan merupakan salah satu potret lembaga pengelola filantropi Islam modern di Indonesia. ${ }^{7}$ Dompet Dhuafa merupakan salah satu Lembaga Amil Zakat non pemerintah yang pertama kali menerapkan manajemen filantropi modern. Pengelolaan zakat pada sebelumnya masih terkesan sangat tradisional dan belum menggunakan manajemen yang belum baik. Dengan adanya sebuah penerapan manajemen filantropi modern, maka Dompet Dhuafa berpeluang mengarahkan dana filantropi Islam yang dikelolanya untuk mendukung inisiatif keadilan sosial. ${ }^{8}$

Pengalaman Dompet Dhuafa yang cukup kaya dalam mengelola dana yang bersumber dari Zakat, Infak dan Sedekah (ZIS) dan wakaf telah banyak dipercaya oleh masyarakat dan juga pemerintah. Saat ini, Dompet Dhuafa mampu menyaingi lembaga amil pemerintah yang mana telah terlebih dahulu hadir seperti (Badan Amil Zakat, Infak dan Sedekah) BAZIS Jakarta. ${ }^{9}$ Namun dengan adanya pengelolaan manajemen yang baik, Dompet Dhuafa kini menjadi pelopor sebagai lembaga yang professional dalam kinerja manajemen lembaganya. ${ }^{10}$

Lembaga Dompet Dhuafa Republika ini penting untuk dikaji, karena ada beberapa perbedaan yang menonjol dari LAZ lainnya di Indonesia. Pertama, Dompet Dhuafa merupakan salah satu lembaga amil zakat non pemerintah yang pertama kali menerapkan manajemen filantropi modern, dahulu pengelolaan zakat di Indonesia masih bersifat tradisional. Kedua, dengan menerapkan filantropi Modern tersebut, Dompet Dhuafa berpeluang juga dalam mengarahkan dana filantropi Islam yang dikelolanya untuk mendukung sebuah inisiatif keadilan sosial. Ketiga, Dompet Dhuafa dilahirkan dari komunitas pers (harian umum Republika) dan cendekiawan muda perkotaan. Keempat, dengan adanya manajemen filantopi Islam tersebut, Dompet Dhuafa telah menciptakan citra positif di kalangan masyarakat perkotaan. ${ }^{6}$ Perkembangan yang cukup baik tentunya, dan Dompet Dhuafa juga banyak mengalami transformasi yang cukup baik yakni dengan adanya program inovasi pada lembaga tersebut. Dompet Dhuafa bukan hanya lembaga zakat tetapi juga menjadi lembaga sosial- kemanusiaan. Lembaga Dompet Dhuafa merupakan salah satu potret perkembangan filantropi Islam terbaik di Indonesia.

Perkembangan Dompet Dhuafa Republika kini telah dapat menyaingi lembaga zakat pemerintah, perjalanan Dompet Dhuafa menuju kesuksesan tersebut perlu dipelajari lebih dalam dan dikaji lebih lanjut, bagaimana keberhasilan Dompet Dhuafa dalam mengelola manajemennya, transformasi Dompet Dhuafa, dan kunci keberhasilan lembaga sehingga Dompet Dhuafa lebih populer ketimbang LAZ lainnya. Penelitian ini akan membahas persoalan tersebut guna mengetahui sepak terjang perkembangan Dompet Dhuafa dan juga transformasi yang terjadi pada Dompet Dhuafa.

\section{Rumusan Masalah}

Permasalahan penelitian ini adalah menguraikan perkembangan transformasi Dompet Dhuafa dari lembaga zakat menjadi lembaga sosialkemanusiaan. Penulis juga membatasi pembahasan penelitian perkembangan Dompet Dhuafa ini, mulai tahun 19932012.

Dari sebuah uraian dari latar belakang penulisan ini, penulis bermaksud mengkaji dan mengungkapkan lebih lanjut akan perkembangan lembaga filantropi

${ }^{6}$ Helmanita, "Mengelola Filantropi Islam", h. 8788 
Islam Indonesia khususnya Dompet Dhuafa yang kini memiliki banyak transformasi (perubahan), dengan demikian rumusan pertanyaan penelitian ini adalah :

1. Bagaimanakah sejarah berdirinya Dompet Dhuafa?

2. Bagaimanakah perkembangan Dompet Dhuafa sebagai Lembaga Amil Zakat?

3. Apa saja peran Dompet Dhuafa sebagai lembaga sosial-kemanusiaan dalam memberikan layanan kepada masyarakat?

4. Bagaimanakah transformasi perkembangan lembaga Dompet Dhuafa $?$

\section{Tujuan dan Manfaat Penelitian \\ Tujuan Penelitian:}

a. Mendeskripsikan proses sejarah berdirinya Dompet Dhuafa.

b. Menguraikan perkembangan Dompet Dhuafa sebagai Lembaga Amil Zakat

c. Menguraikan sebuah peran sosialkemanusiaan Dompet Dhuafa dan juga transformasi perkembangan lembaga Dompet Dhuafa

\section{Manfaat Penelitian:}

a. Menambah wawasan intelektual khususnya mengenai sejarah berdirinya lembaga zakat Dompet Dhuafa.

b. Memberikan informasi kepada pembaca khususnya mengenai lintasan perkembangan sejarah Dompet Dhuafa Republika selama tahun 1993-2012. c. Dapat dijadikan sebagai bahan kajian baru untuk memperkaya khazanah sejarah filantropi Islam di Indonesia.

\section{Tinjauan Pustaka}

Secara umum pembahasan mengenai Dompet Dhuafa Republika atau lembaga filantropi Islam ada beberapa buku di antaranya:

Buku rujukan adalah Revitalisasi Filantropi Islam Studi Kasus Lembaga Zakat dan Wakaf di Indonesia, Irfan Abubakar dan Chaider S Bamualim sebagai editornya. Buku ini berisi seputar berbagai potret lembaga filantropi Islam di Indonesia dan menganalisis pengaruh tradisi, struktur dan institusi dalam membentuk karakteristik lembaga filantropi Islam di Indonesia. Perkembangan Lembaga Amil Zakat di Indonesia serta konteks sosial politik yang banyak mempengaruhi dinamika lembagalembaga tersebut. Bagi penulis, buku ini cukup memberikan informasi yang cukup mengenai Dompet Dhuafa untuk bahan penelitian, akan tetapi buku ini berisi kumpulan-kumpulan tulisan dengan pembahasan yang berbeda tiap point bab nya dan diperlukan ketelitian guna menyambungkan pembahasan selanjutnya. ${ }^{7}$

Buku yang ditulis Ahmad Juwaini, dengan judul Social Enterprise Transformasi Dompet Dhuafa menjadi World Class Organization. Buku ini banyak berisi penjelasan mengenai bagaimana mengelola strategi organisasi, rencana strategis, dan mengenai perkembangan perubahan perjalanan Dompet Dhuafa di mana penjelasan dari masa awal hingga kini, dan juga mengenai penjelasan Social Enterprise. Bagi penulis buku ini memiliki kontribusi yang cukup banyak dimana dapat lebih mengetahui sejauh apa dan bagaimana perjalanan Dompet Dhuafa tersebut dapat bertransformasi dengan baik, bahkan informasi dalam buku ini adalah

\footnotetext{
${ }^{7}$ Bamualim dan Bakar, ed., Revitalisasi Filantropi Islam Studi Kasus lembaga Zakat
} 
transformasi menuju World Classs Organization. $^{8}$

Selain itu, ada buku yang memberikan informasi yang cukup banyak. Buku yang ditulis Amelia Fauzia, dengan judul Faith and the State a History of Islamic Philantrophy In Indonesia. Buku ini mencakup Fiqh dan konsep zakat, sejarah filantropi di masa Pra kolonial, kolonial, perkembangan masa awal kemerdekaan Indonesia dan juga berisi dinamika perjalanan sejarah Filantropi Islam, perkumpulan pembahasan Lembaga Amil Zakat dan Badan Amil Zakat di Indonesia. Dalam buku ini, penulis mendapat informasi yang cukup banyak khususnya mengenai awal sejarah Filantropi Islam di Indonesia dan juga perkembangannya hingga tahun 2013, selain itu pembahasan perkembangan Lembaga Amil Zakat di Indonesia. ${ }^{9}$

\section{Metode Penelitian}

1. Jenis Penelitian

Maksud penelitian ini untuk mengkaji dan mengungkapkan sejarah perkembangan dan transformasi Dompet Dhuafa. Adapun Skripsi ini merupakan sejarah kontemporer, karenanya metode penelitian yang digunakan dalam penelitian ini adalah metode historis. ${ }^{10}$ Lebih deskriptif-analitis terhadap gambaran dan penguraian sejarah perkembangan Dompet Dhuafa.

8 Juwaini, Social Enterprise Transformasi Dompet Dhuafa Menjadi World Class Organization, (Jakarta: Expose (Mizan Group) Anggota IKAPI, 2011), cet I.

${ }^{9}$ Fauzia, Faith and The state

10 Metode historis merupakan suatu proses menguji dan menganalisa secara kritis sebuah rekaman dan sebuah peninggalan masa lampau. Lihat dalam Louis Gottschalk, Mengerti Sejarah terj. Nugroho Notosusanto, (Jakarta:UI Press, 1983), h.32
2. Lokasi Penelitian dan Waktu Penelitian

Lokasi penelitian ini adalah Ciputat-Tangerang Selatan dan Jakarta. Penelitian ini dilakukan selama dua bulan, dikarenakan adanya suatu hambatan dan juga adanya perubahan jadwal pertemuan wawancara, akan tetapi dapat teratasi sesuai dengan kemampuan penulis.

\section{Sumber Data \\ a. Sumber Data Primer \\ Data primer merupakan} beberapa data yang djadikan rujukan utama dalam proses penulisan keilmiahan. Cerita atau penuturan, catatan dari para saksi mata tentang terjadinya suatu peristiwa. Biasanya data primer berupa dokumen atau catatan yang ditulis oleh saksi mata berkenaan dengan suatu peristiwa. $^{24}$ Kesaksian $^{2}$ lisan termasuk sumber primer misalnya saja penuturan dari saksi saat peristiwa terjadi yang diungkapkan secara lisan. ${ }^{11}$

Dalam usaha mendapatkan data ini, penulis melakukan kunjungan ke kantor Dompet Dhuafa pusat. Penulis melakukan wawancara dengan pelaku sejarah sekaligus pimpinan Dompet Dhuafa. Bapak Ahmad Juwaini, beliau merupakan presiden direktur pada saat penulis menemuinya.

\section{b. Sumber Data Sekunder}

Sedangkan data sekunder merupakan cerita atau penuturan mengenai suatu peristiwa yang tidak disaksikan oleh pelapor, melainkan hanya melaporkan apa yang dituturkan

\footnotetext{
${ }^{11}$ Dokumen yang termasuk sumber primer adalah Undang-undang dasar, Piagam, otobiografi, dan sebagainya. Barang peninggalan yang menjadi sumber primer misalnya fosil, kerangka, perkakas, dan sebagainya. Lihat Nurul Zuriah, Metode Penelitian Sosial dan Pendidikan Teori-Aplikasi, (Jakarta: PT Bumi Aksara, 2007), h. 56
} 
atau ditulis oleh orang yang menyaksikan peristiwa itu.

\section{Metode Pengumpulan Data}

Pengumpulan data dalam

penelitian ini dilakukan melalui:

a. Observasi Lapangan

Observasi dilakukan dengan cara melakukan penelitian terjun langsung kepada orang yang mengetahui sejarah tersebut. Dalam hal ini, penulis melihat dan survey langsung ke lapangan, interview (wawancara) juga digunakan pada observasi ini. Penulis juga mencari data-data disana, dalam hal ini penulis berkordinasi dengan saudari Zilhaf Zii dan Ibu Puji Astuti yang merupakan bagian CorSec (Corporate Secretary), penulis mendapatkan data-data yang mendukung bahan penelitian.

\section{b. Interview (Wawancara) ${ }^{12}$}

Sebagai salah satu sumber dalam skripsi ini, karena penulis juga melakukan wawancara kepada tokoh atau pimpinan Dompet Dhuafa, salah satu lembaga yang bekerja sama dengan Dompet Dhuafa, wawancara ini untuk membantu atau mencarikan informasi mengenai penelitian yang sedang dilakukan penulis.

Penulis dalam hal ini mewawancarai Bapak M. Sabeth Abillawa yang merupakan Jendral Manager Dompet Dhuafa, Bapak Gerald Reza Lasut yakni kepala Markas PMI

\footnotetext{
12 Wawancara bertujuan mengumpulkan keterangan mengenai kehidupan manusia dalam suatu masyarakat, hal ini merupakan pembantu utama dari metode observasi, wawancara ini tergolong wawancara terencana yaitu terdiri dari suatu daftar pertanyaan yang telah direncanakan dan disusun sebelumnya, pencatatan data wawancara yang dilakukan dengan menggunakan alat recording guna mencatat jawaban secara tepat sampai ke detil-detil yang kecil. Lihat Koentjaraningrat, "Metode Wawancara" dalam Koentjaraningrat, ed., Metode-Metode Penelitian Masyarakat, (Jakarta: PT Gramedia Pustaka Utama,hh 1997), h. 129
}

Tangerang Selatan dan Bapak Ahmad Juwaini selaku Presiden Dompet Dhuafa.

\section{c. Studi Kepustakaan}

Studi kepustakaan yaitu menelusuri sumber data dari berbagai bacaan, baik yang bersifat primer maupun yang bersifat sekunder dan juga memiliki banyak tujuan-tujuan ${ }^{30}$ yang mendukung. Adapun penulis mengumpulkan data penelitian ini dengan melakukan ke beberapa perpustakaan di antaranya seperti perpustakaan Utama UIN Jakarta, Perpustakaan Nasional, Perpustakaan IMZ, dan website seperti http://www.dompetdhuafa.org yang terkait dengan perkembangan Dompet Dhuafa dan Filantropi Islam serta mencari berbagai sumber-sumber lain yang ada kaitannya.

\section{Analisis Data}

Analisis data merupakan suatu bagian yang sangat penting dalam metode ilmiah. Data yang sudah penulis kumpulkan setelah itu diedit dan kemudian diklasifikasikan untuk dikategorikan selanjutnya. Data yang sudah terkumpul tersebut di pilah berdasarkan subjek kajian. Dalam hal ini, tahap kategorisasi bertujuan untuk mengelompokkan setiap data ke dalam unit-unit analisis berdasarkan kesesuaian antara satu tema dengan tema lainnya, sehingga hasilnya akan menggambarkan suatu keseluruhan analisis data.

\section{Langkah Penelitian}

Langkah yang dilakukan penelitian ini di antaranya yaitu pertama, heuristik (pengumpulan sumber), penulis mengumpulkan datadata dokumen serta melakukan wawancara kepada tokoh. Adapun penelusuran sumber data primer dan sekunder dilakukan ke perpustakaan- 
perpustakaan, untuk mendapatkan sumber informasi yang cukup. Selain itu beberapa sumber lainnya seperti jurnaljurnal atau dokumen, baik internal Dompet Dhuafa maupun luar, koran dan majalah. $^{13}$

Pada penelitian ini juga melakukan wawancara, dimana penulis mencari dan memilih responden atau narasumber berdasarkan jenis data yang dibutuhkan meliputi saksi sejarah atau pelaku Dompet Dhuafa, salah satu kerjasama jejaring Dompet Dhuafa guna mendapatkan data-data seputar penelitian. Kedua, verifikasi (Pengujian), pengujian dengan kritik dilakukan untuk menguji data-data tersebut untuk menjadi bahan kajian penelitian. Ketiga, interpretasi (penafsiran), penafsiran dilakukan dengan menjelaskan data-data yang didapat secara terperinci sesuai dengan topik pembahasan penelitian. Penulis melakukan pembagian yakni seperti periode waktu (periodisasi) Dompet Dhuafa, struktur lembaga, dan juga program- program lembaga, dan keempat, historiografi yakni proses penulisan yang sesuai dengan metode penulisan penelitian. ${ }^{34}$

Adapun pedoman penulisan yang digunakan oleh penulis adalah Pedoman Penulisan Karya Ilmiah (Skripsi, Tesis dan Disertasi) yang diterbitkan oleh CeQDA UIN Syarif Hidayatullah Jakarta tahun 2007.

\section{B. Pembahasan}

\section{ANALISIS TRANSFORMASI DOMPET DHUAFA}

Dompet Dhuafa setahap demi setahap semakin berkembang dengan

13 Pengumpulan data-data atau sumber yang terkait dengan objek. Lihat Kuntowijoyo, Pengantar Ilmu Sejarah, (Yogyakarta: Bentang Pustaka, 2005),hlm. 99-100. baik, peningkatan yang terjadi pada Dompet Dhuafa tersebut, tentunya memiliki sebuah dorongan atau dasar yang cukup berpengaruh, sehingga Dompet Dhuafa dapat menjadi lembaga yang sangat besar. Dalam pembahasan ini, penulis akan menjelaskan analisa transformasi Dompet Dhuafa ini menjadi dua faktor. Faktor tersebut yakni faktor internal dan faktor eksternal. Faktor internal merupakan dimana adanya suatu motivasi dan rencana strategi khusus dari para tokoh pendiri lembaga untuk dapat mengembangkan Dompet Dhuafa. Sedangkan faktor eksternal yakni adanya Reformasi dan pengaruhnya terhadap Lembaga Amil Zakat, dan kebangkitan lembaga sosialkemanusiaan setelah terjadi peristiwa bencana di Indonesia.

\section{A. Faktor Internal}

Pembahasan dari segi faktor internal ini, penulis berusaha menjelaskan dari internal (dalam) lembaga Dompet Dhuafa. Dalam hal ini, yang menjadi pembahasan tersebut adalah adanya suatu motivasi dan rencana strategi khusus dalam individu tokoh untuk dapat mengembangkan Dompet Dhuafa. Motivasi dan rencana strategis itu, tertuang dalam penjelasan yakni nilai semangat Islami, sumber daya manusia yang berkualitas, dukungan donatur, perkembangan struktur dan program Dompet Dhuafa.

\section{Nilai Semangat Islami}

Bila melihat kembali sejarah awal berdirinya yayasan Dompet Dhuafa, yayasan ini berdiri dari kelompok wartawan, yang mana bermula dari perbincangan dengan teman-teman yang berasal dari Corps Dakwah Pedesaan (CDP). Dalam perbincangan tersebut, ${ }^{146}$ banyak wartawan Republika yang tergerak 
hatinya. Perbincangan dalam pertemuan itu, terjadi di Yogyakarta. Pertemuan tersebut, menimbulkan rasa simpati dan juga empati bagi wartawan yang mendengar perbincangan saat itu. Setelah peristiwa yang mereka alami pada waktu itu, mereka memunculkan ide untuk dapat saling membantu sesama yakni dengan cara menggalang dana.

Dari peristiwa tersebut, penulis mengambil suatu kesimpulan. Dompet Dhuafa berdiri atas dasar nilai semangat yang kuat, di samping itu para tokoh Dompet Dhuafa memiliki rasa peduli yang tinggi (atas pengalaman dari perbincangan CDP tersebut). Organisasi lahir dari semangat mengamalkan ajaran-ajaran agamanya, karena itu orang-orang yang bekerja di Dompet Dhuafa lebih dari sekedar bekerja saja. Orang yang bekerja di Dompet Dhuafa merasakan bahwa bekerja di lembaga ini merupakan suatu pengabdian, pelayan umat, dan juga pembantu umat, yang dilakukan tersebut merupakan salah satu bagian mengamalkan pengajaran agama. ${ }^{14}$

Kepercayaan merupakan suatu amanah yang harus di jaga dengan sebaik- baiknya, dan kelak akan di pertanggungjawabkan kepada Sang Pencipta. ${ }^{15}$ Nilai semangat Islami ini terlihat dari adanya rasa semangat, rasa peduli, dan saling membantu kepada sesama.

\section{Kualitas Sumber Daya Manusia}

\footnotetext{
14 Wawancara dengan Bapak Ahmad Juwaini (Presiden Direktur Dompet Dhuafa), 9 Oktober 2013

15 Ahmad Juwaini, Social Enterprise Transformasi Dompet Dhuafa Menjadi World Class Organization, (Jakarta: Expose (Mizan Group) Anggota IKAPI, 2011), cet I, h. 242-243
}

Dompet Dhuafa ketika berdiri dipegang oleh beberapa kalangan wartawan. Parni Hadi, Erie Sudewo, Haidar Baqir, dan S. Sinansari Ecip yang mana mereka merupakan tokoh jurnalis yang memulai mendirikan Dompet Dhuafa Republika. Kalangan wartawan merupakan orang-orang yang memiliki pendidikan yang cukup tinggi, dan memiliki pengetahuan. Pendidikan para wartawan atau pendiri tersebut, rata-rata strata 1 (S1). Di samping pendidikan yang tinggi, para wartawan tersebut juga sudah mempunyai cukup pengalaman, dimana pernah bekerja dalam harian nasional Republika. Wartawan merupakan profesi awal para pendiri Dompet Dhuafa, dimana pekerjaan wartawan adalah mencari berita dan mengelola berita dengan baik kepada khalayak publik. Pengalaman yang cukup lama sebagai wartawan tersebut merupakan awal yang cukup baik bagi Dompet Dhuafa untuk dapat menjalankan dan mengelola lembaganya.

Dompet Dhuafa sebagai lembaga yang berkembang, memiliki sumber daya manusia yang berkualitas dan cukup baik. Sumber daya manusia merupakan karyawan yang bekerja di Dompet Dhuafa. Karyawan yang bekerja dalam lembaga ini mempunyai persyaratan umum dan persyaratan khusus, ${ }^{16}$ dimana calon karyawan diseleksi terlebih dahulu, kemudian diberi pembekalan berupa pelatihanpelatihan yang cukup. Pembekalan ini merupakan upaya-upaya

Dompet Dhuafa untuk meningkatkan kualitas SDM nya. Upaya untukmeningkatkan kualitas SDM Dompet Dhuafa ada banyak misalnya saja pelatihan-pelatihan khusus, seminar, outbond, dan lain-lain. Selanjutnya berbeda dengan

16 Lihat dalam Dokumen Dompet Dhuafa Republika menuju Millenium III, h. 7 
sebelumnya, karyawan Dompet Dhuafa yang berprestasi tak akan selamanya duduk hanya menjadi staf atau asisten manajer. Karyawan yang berprestasi akan dipromosikan menjadi pimpinan diberbagai bidang yang siap diterjunkan ke masyarakat atau akan diberikan (reward) penghargaan sesuai dengan prestasinya tersebut. ${ }^{17}$ Adanya sumber daya manusia yang cukup baik, mendorong Dompet Dhuafa untuk dapat mengelola dan mengatur sistem manajemen lembaganya dengan baik.

Manajemen yang digunakan Dompet Dhuafa merupakan manajemen mengadopsi manajemen suatu perusahaan, hal tersebut terlihat dari struktur nya yang memiliki waktu dan jam kerja karyawan dan juga banyaknya divisi-divisi yang digunakan. Perubahan manajemen modern ini cukup baik, berbeda dengan masa lalu dimana pengelolaan masih bersifat tradisional. Yang utama adalah Dompet Dhuafa mengembangkan organisasinya secara professional. Karena sebuah professional itu akhirnya menjadikan kultur lembaga, sehingga pengelolaan zakat kini tidak menjadi tradisional. Bila melihat masa lalu, orang mengurusi mengelola zakat hanya berbentuk kepanitiaan saja, tapi kini pekerja masuk 8 jam sehari dan masuk 5 hari kerja dan sudah berkembang dengan menggunakan sistem karyawan atau kepegawaian. Jadi proses tersebut mengakibatkan Dompet Dhuafa menjadi lembaga yang semakin tumbuh. Selain itu, ditambah dengan adanya inovasi dalam lembaga ini, mulai dari program-program lembaga yang cukup baik dan akhirnya membuat

17 Karyawan yang berprestasi maka akan ada penilaian prestasi kerja, lihat dalam "Ketentuanketentuan Pokok Kepegawaian yayasan Dompet Dhuafa Republika" lihat dalam Dokumen Dompet Dhuafa Republika menuju Millenium III.
Dompet Dhuafa menjadi lembaga yang dikenal oleh masyarakat. ${ }^{151}$ 


\section{Perkembangan Struktur dan program Dompet Dhuafa}

\begin{tabular}{|c|c|c|c|c|}
\hline \multirow{2}{*}{\multicolumn{2}{|c|}{ NUraian }} & \multicolumn{3}{|c|}{ Periode } \\
\hline & & $\begin{array}{l}\text { Periode awal perintisan DD } \\
(1993-1998)\end{array}$ & $\begin{array}{l}\text { Periode transisi DD (1999- } \\
\text { 2003) }\end{array}$ & $\begin{array}{l}\text { Periode sosial-kemanusiaan DD (2004- } \\
\text { 2012) }\end{array}$ \\
\hline & Struktur yang & $\begin{array}{l}\text { Pada periode ini struktur } \\
\text { dompet yang di gunakan adalah } \\
\text { truktur LAZ standard dan terak } \\
\text { di gunakan pada tahun } 1997 .\end{array}$ & $\begin{array}{l}\text { Pada periode transisi } \\
\text { struktur yang di gunakan } \\
\text { adalah JMK (Jejaring Multi } \\
\text { Koridor) yang di laksanakan } \\
\text { pada tahun } \\
2000\end{array}$ & $\begin{array}{l}\text { Struktur yang di gunakan pada tahun } \\
2004 \text { tidak ada perubahan. Pada tahun } 2 \\
\text { struktur DD berubah nama menjadi DD } \\
\end{array}$ \\
\hline & Penjabaran/ & $\begin{array}{l}\text { Bila melihat bagian-bagian } \\
\text { struktur LAZ standar, struktur i } \\
\text { masih sederhana dan tugas masir } \\
\text { masing divisi masih ada yang } \\
\text { angkap dan saling menghandle. } \\
\text { Struktur ini terdiri dari badan } \\
\text { pendiri, dewan syariah, direktur, } \\
\text { penghimpunan, keuangan dan } \\
\text { administrasi, pendayagunaan }\end{array}$ & $\begin{array}{l}\text { Struktur JMK ini semakin } \\
\text { berkembang. Dalam } \\
\text { penjabarannya ada } 5 \text { VP. } \\
\text { Struktur ini terdiri dari: CEO } \\
\text { (presiden direktur), VP jejari } \\
\text { LPZ, VP jejaring asset Refor } \\
\text { NP Kendali jejaring, VP } \\
\text { ejaring bisnis, VP, jejaring } \\
\text { asset sosial. }\end{array}$ & $\begin{array}{l}\text { Perubahan Struktur DD Net ini tidak } \\
\text { jauh berbeda dengan strktur sebelumnya. } \\
\text { DD Net merupakan struktur yang di } \\
\text { sesuaikan dengan keperluan dan kebutuh } \\
\text { embaga. Struktur ini terdiri } 8 \\
\text { pagiandiantaranya: LAZ, relief danlain- } \\
\text { lain, pendidikan, kesehatan, Community } \\
\text { enterprise, holding bisnis. TWI, cabang. }\end{array}$ \\
\hline & Perkembangan & $\begin{array}{l}\text { Stuktur yang digunakan ini } \\
\text { tidak lama, terakhir pada tahun } \\
1997 .\end{array}$ & $\begin{array}{l}\text { Struktur jejaring Multi } \\
\text { Koridor ini sangat membant } \\
\text { dalam } \\
\text { menghandle program dompe } \\
\text { dhuafa }\end{array}$ & $\begin{array}{l}\text { DD Net ini akan mengalami } \\
\text { perubahan. DD Net } 2013 \text { tidak jauh } \\
\text { perbeda dengan DD net } 2009 \text {, karena } \\
\text { struktur tersebut sudah dua kali modifika } \\
\text { Struktur ini terdiri dari } 9 \text { bagian } \\
\text { diantaranya LAZ, relief danlain-lain, } \\
\text { pendidikan, kesehatan, Community } \\
\text { enterprise, holding bisnis. TWI, cabang } \\
\text { yayasan RST. }\end{array}$ \\
\hline
\end{tabular}

Struktur merupakan hal yang
sangat mempengaruhi tentunya
dalam pembagian tugas masing-masing program. Struktur Dompet Dhuafa mengalami perubahan yang cukup. Berawal Dompet Dhuafa yang dititipkan tanpa petunjuk; konsep, visi, misi, tujuan, arah dan target. ${ }^{152}$ Pada tahun pertama, Dompet Dhuafa menggunakan struktur yang diibaratkan "pentol korek", kemudian selanjutnya struktur LAZ standar sampai tahun 1997, Jejaring Multi Koridor (JMK) yang dimulai pada tahun 2000, hingga pada tahun 2009 struktur yang digunakan bernama DD Net dan dimodifikasi menjadi DD Net 2013. Dari penjabaran tabel tersebut menjelaskan bahwa struktur yang digunakan semakin lama semakin berkembang seiring dengan bertambah atau berkembangnya program Dompet Dhuafa. Berikut ini adalah tabel transformasi program Dompet Dhuafa. 
Tabel program-program Dompet Dhuafa

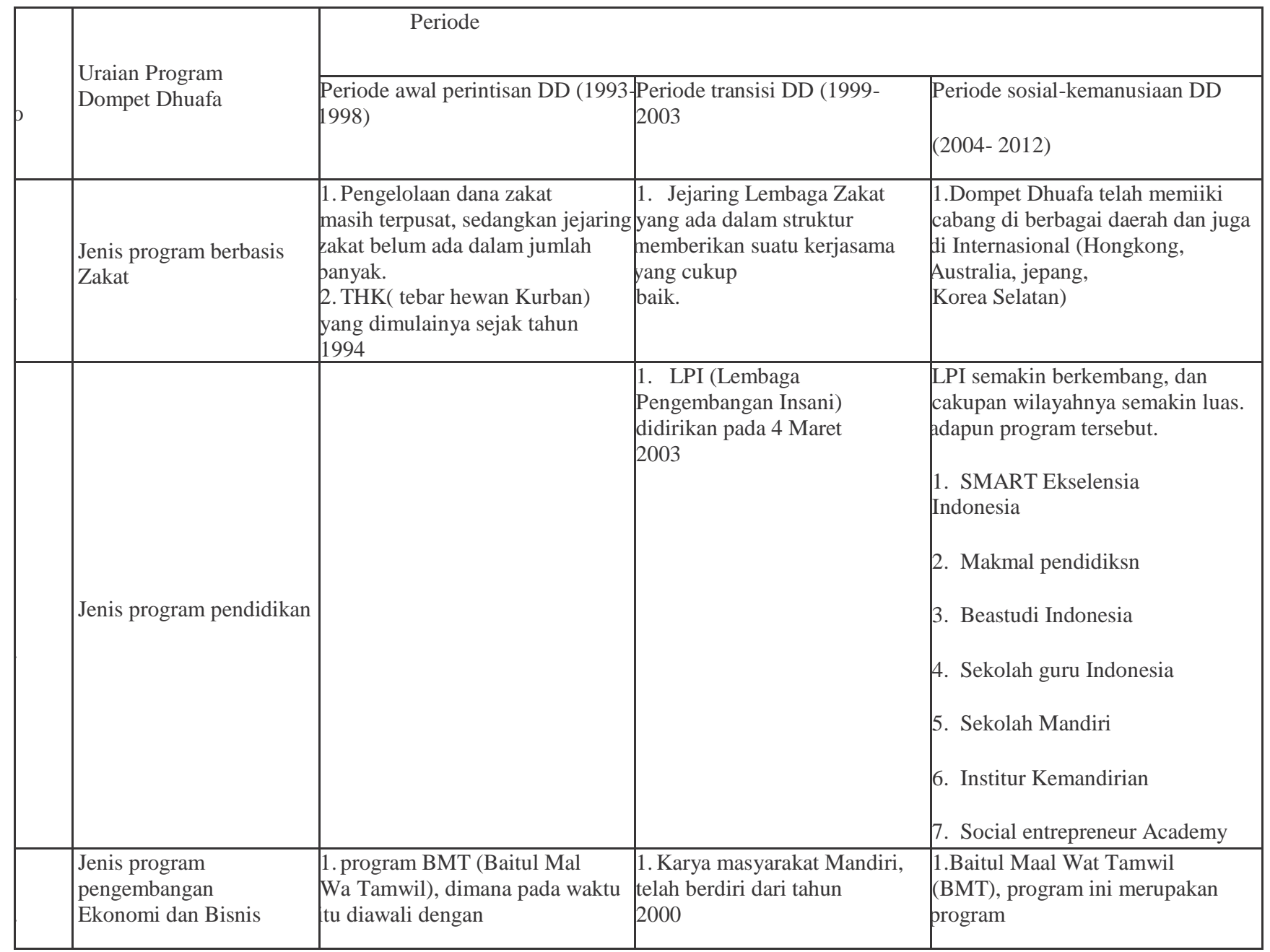




\begin{tabular}{|c|c|c|c|c|}
\hline & & $\begin{array}{l}\text { pelatihan manajemen ZIS } \\
\text { dan Ekonomi syariah pada tahun } \\
\text { 1994 } \\
\text { 2. ada Usaha Hasil Tani yang } \\
\text { diilhami oleh proyek padi } \\
\text { Lamongan pada tahun } 1994 . \\
\text { 3. ITTARA, Industri Tepung } \\
\text { Tapioka Rakyat yang didirikan di } \\
\text { ampung tahun } \\
\text { 1995. } \\
\text { 4. ada Raudha Rahma Abadi yang } \\
\text { mana didirikan pada tahun } 1996\end{array}$ & $\begin{array}{l}\text { 2. Kampung Ternak } \\
\text { Nusantara } \\
\text { 3. Pertanian sehat Indonesia } \\
\text { yang berdiri tahun } 1999 \\
\text { 4. Klaster } \\
\text { Mandiri(pembangunan kawasan } \\
\text { desa secara terpadu dan } \\
\text { perdimensi zakat) } \\
\text { 5. Social Trust Fund } \\
\text { 6. terdapatnya IMZ (Institut } \\
\text { Manajemen Zakat), yang lahir } \\
\text { pada akhir tahun 1999 } \\
\text { 7. DD Travel. DD Travel hadir } \\
\text { pada tahun 2004, merupakan } \\
\text { perkembangan Raudha Rahma } \\
\text { Abadi } \\
\text { 8. Tahun 1999, Dompet Dhuafa } \\
\text { melahirkan program Masyarakat } \\
\quad \text { Mandiri (MM). }\end{array}$ & $\begin{array}{l}\text { pemberdayaan kaum dhuafa } \\
\text { yang dirintis pada tahun } 2007 \\
\text { 2.DD livestock (pemasaran ternak), } \\
\text { didirikan juli } 2009 \text { dan merupakan } \\
\text { pemekaran dari kampoeng ternak. } \\
\text { 3.DD Water } \\
\end{array}$ \\
\hline & $\begin{array}{l}\text { Jenis program sosial- } \\
\text { kesehatan }\end{array}$ & & \begin{tabular}{|l|} 
1.Selanjutnya ada LKC \\
(layanan Kesehatan Cuma- \\
Cuma) pada 6 November \\
2001 \\
2. LPM (Lembaga Pelayan \\
Masyarakat), yang telah berdiri \\
ahun 2003, dahulu \\
bernama layanan Mustahik. \\
memilki kegiatan seperti \\
ayanan mustahik, layanan \\
santunan,rumah sahabat anak, \\
enovasi musholla, bersih itu \\
ehat, bimbingan rohani pasien, \\
ayanan jenazah
\end{tabular} & $\begin{array}{l}\text { 1. Semesta Hijau Indonesia. } \\
\text { Kegiatan seperti sedekah pohon, air } \\
\text { intuk kehidupan, } \\
\text { perbaruan energy dan pengelolaan } \\
\text { imbah } \\
\text { 2. program yang dinamakan } \\
\text { Zona Madina. di awal tahun } \\
\text { 2012, Rumah Sakit (RS) Rumah } \\
\text { Sehat Terpadu Dompet Dhuafa } \\
\text { elah } \\
\text { beroperasi }\end{array}$ \\
\hline & $\begin{array}{l}\text { Jenis program } \\
\text { kemanusiaan }\end{array}$ & $\begin{array}{l}\text { 1. Aksi Cepat Tanggap (ACT), } \\
\text { pada tahun } 1994 \text { sudah } \\
\text { peraktivitas }\end{array}$ & $\begin{array}{l}\text { 1. SPM (Sahabat Pekerja } \\
\text { Migran). Yangberdiri } 3 \text { Juli } \\
2003 \\
\text { 2. Daerah persebaran yang di } \\
\text { pantu ACT semakin banyak }\end{array}$ & $\begin{array}{l}\text { 1.DMC Dompet Dhuafa (Disaster } \\
\text { Manajemen Center Dompet } \\
\text { Dhuafa. Pada tanggal } 25 \\
\text { Maret 2010, } \\
\text { 3. Migrant Institute } \\
\text { 4. Program bantuan untk Gaza, } \\
\text { Palestina } \\
\text { 5. Distribusi bantuan untuk Irak, } \\
\text { Afghanistan dan Myanmar. }\end{array}$ \\
\hline
\end{tabular}

Penjabaran tersebut merupakan program yang sudah dikategorikan oleh penulis. Bila melihat tabel tersebut, terlihat Dompet Dhuafa memiliki program yang cukup banyak selain program zakatnya. Penulis mengkategorisasikan program tersebut sesuai dengan munculnya program tersebut dan juga semua program yang pernah dijalankan di masyarakat, hampir sebagian besar program pendidikan dan ekonomi juga bagian program sosial-masyarakat, yang bertujuan membantu masyakarat.

Program sosial-kemanusiaan mulai bermunculan pada periode transisi Dompet Dhuafa dan semakin berkembang pada periode sosialkemanusiaan. Program-program tersebut dapat terlihat seperti LKC (Layanan Kesehatan Cuma-Cuma), LPM (Lembaga Pelayan Masyarakat), DMC (Disaster Manajemen Center) dan program lainnya. Program yang 
semakin berkembang dimasyarakat menjadikan Dompet Dhuafa sebagai lembaga terpercaya dan mudah dikenal oleh masyarakat. Kepercayaan (trust) ini merupakan tanggung jawab lembaga, dimana harus dijalankan dan di pertanggungjawabkan dengan baik. Kepercayaan membuat Dompet Dhuafa semakin mengalami perkembangan yang cukup baik. Semakin banyaknya kepercayaan yang di dapat oleh masyarakat, donatur ataupun CSR (Corporate Sosial Responsibility), maka akan semakin banyak yang bekerja sama dan mengenal baik Dompet Dhuafa.

\section{Dukungan Donatur Dompet Dhuafa}

Dukungan donatur yang baik merupakan suatu jalinan hubungan komunikasi yang cukup baik pula. Bila dari pengalaman Dompet Dhuafa, dukungan yang cukup dari para donatur tersebut memiliki alasan atau harapan khusus sehingga para donatur banyak yang mendukung aktivitas programprogram Dompet Dhuafa. Maka dapat disimpulkan alasan atau harapan donatur dalam mendukung aktivitas lembaga diantaranya adalah :

a. Sesuainya dengan ajaran Islam. Dalam hal ini, pandangan donatur tersebut bahwa perbuatan berderma merupakan suatu kategori ibadah sehingga wajib dijalankan sesuai dengan ajaran Islam.

b. Bermanfaat bagi kaum Dhuafa. Bagi donatur, berderma yang ia berikan harus sampai kepada orangorang yang membutuhkan.

c. Tanggung jawab dan transparansi lembaga pengelola. Lembaga yang dititipi amanah harus dapat mengelola, mempertanggungjawabkan dan menjaga amanah tersebut. $^{18}$

\footnotetext{
${ }^{18}$ Ahmad Juwaini, "Pengalaman Dompet Dhuafa Republika", lihat dalam Idris Thaha, Ed.,
}

Selain itu, dalam menyalurkan dananya, para donatur mempunyai harapan pemanfaatan dana untuk program lembaga. Berikut tabel harapan keinginan pemanfaatan dana dari donatur untuk program:

Tabel Keinginan Donatur melalui pemanfaatan dana untuk program

\begin{tabular}{|c|c|}
\hline JENIS PROGRAM & PERSENTASE \\
\hline $\begin{array}{llr}\text { Pengembangan } & \text { Ekonomi } & \text { Menyantun } \\
\text { Anak yatim } & \text { Pengembangan } & \text { SDM } \\
\text { Bantuan Bencana Alam Lainnya } & \end{array}$ & $\begin{array}{c}25 \% \\
28 \% \\
20 \% \\
19 \% \\
8 \%\end{array}$ \\
\hline Jumlah & $100 \%$ \\
\hline
\end{tabular}

(Sumber :Survei Donatur Dompet Dhuafa, 1998) $)^{19}$

Pemanfaatan dana dari jenis program menyantuni anak yatim merupakan persentase yang tertinggi yaitu $29 \%$, dilanjutkan pengembangan ekonomi $25 \%$. Selain itu, bantuan bencana alam sebesar $19 \%$, persentase tersebut menandakan bahwa Donatur Dompet Dhuafa bukan hanya memberikan dana zakat atau pengembangan ekonomi saja, tapi untuk bantuan bencana alam juga ikut membantu. Harapan keinginan donatur dalam pemanfaatan dana untuk program yang dijalankan tersebut merupakan hal yang sangat penting, karena hal tersebut merupakan amanah dan tanggung jawab yang harus dijalankan.

Dompet Dhuafa memiliki tradisi yaitu sebuah keterbukaan. Caranya dengan melatih kejujuran dan berani bertanggung jawab. Dengan begitu sikap saling percaya tersebut di

Berderma Untuk Semua Wacana dan Praktik Filantropi Islam, ( Jakarta: Pusat Bahasa dan Budaya UIN Jakarta dan Teraju, 2003), h. 269270

19 Juwaini, "Pengalaman Dompet Dhuafa Republika", lihat dalam Idris Thaha, Ed. Berderma Untuk Semua, , h. 270 
tumbuhkan dari dalam. Adanya sebuah indikator yang dimiliki Dompet Dhuafa, yang dimulai pada periode tahun 2010 hingga 2015, indikator tersebut merupakan suatu alat ukur kinerja lembaga. ${ }^{156}$ Salah satu indikator tersebut yang telah berhasil di capai seperti berpartisipasi aktif dalam forum dan misi kemanusiaan di tingkat internasional, menjadi lembaga yang expert dalam bidang pengentasan kemiskinan, dan menjadi organisasi kepedulian di 10 kota besar di Indonesia. $^{20}$

Indikator yang telah tercapai tersebut merupakan suatu perjalanan perkembangan Dompet Dhuafa sebagai pertanda bahwa Dompet Dhuafa merupakan lembaga sosialkemanusiaan, tetapi tidak melupakan tugas awalnya sebagai lembaga amil zakat. Suatu lembaga dapat berkembang dengan baik, tentunya harus memiliki sebuah ide, strategi dan juga sebuah terobosan-terobosan terbaru guna mempromosikan lembaganya agar tetap berkiprah atau tetap eksis berdiri baik. Secara internal, Dompet Dhuafa memiliki rencana strategis yang cukup matang seperti adanya penguatan kelembagaan, ${ }^{158} \quad$ inovasi, ${ }^{159}$ kemitraan, ${ }^{160}$ aliansi, ${ }^{161}$ transformasi nilai. ${ }^{162}$ Tetapi untuk dapat berkembang dengan baik tentu tak cukup dengan itu semua, yang utama adalah suatu kepercayaan (trust).

${ }^{20}$ Penulis memaparkan baru point yang tercapai dari Indikator keberhasilan lembaga yang berjumlah 14 point, lihat dalam Juwaini, Social Enterprise Transformasi Dompet Dhuafa menjadi World Class Organization, (Jakarta : Expose (Mizan Group), 2011), h.74-75 
Berikut merupakan tabel penerimaan dana Dompet Dhuafa tahun 2008-2012.

Tabel Laporan Penerimaan Dana Dompet Dhuafa tahun 2008-2012

\begin{tabular}{|l|l|l|l|l|l|}
\hline $\begin{array}{l}\text { Ienis } \\
\text { Dana }\end{array}$ & 2008 & 2009 & 2010 & 2012 & \\
\hline Zakat & $43.357 .557 .063,00$ & $52.880 .579 .880,00$ & $60.640 .900 .919,00$ & $75.523 .980 .061,00$ & $95.482 .152 .933,87$ \\
\hline $\begin{array}{l}\text { Infak/se } \\
\text { dekah }\end{array}$ & $18.921 .994 .897,00$ & $9.029 .965 .993,00$ & $9.191 .663 .417,00$ & $14.762 .598 .052,00$ & $25.724 .960 .378,30$ \\
\hline Wakaf & $2.307 .195 .678,00$ & $4.969 .640 .141,00$ & $45.657 .392 .727,00$ & $37.498 .130 .992,00$ & $7.688 .309 .084,00$ \\
\hline $\begin{array}{l}\text { Keman } \\
\text { usian }\end{array}$ & $455.118 .261,00$ & $11.667 .416 .578,00$ & $9.200 .108 .061,00$ & $1.649 .796 .118,00$ & $2.859 .891 .479,50$ \\
\hline Kurban & $12.138 .207 .000,00$ & $16.997 .624 .000,00$ & $19.750 .509 .332,00$ & $19.627 .757 .524,00$ & $23.944 .765 .332,00$ \\
\hline $\begin{array}{l}\text { Dana } \\
\text { Lain }\end{array}$ & $-1.470 .274 .509,00$ & $45.854 .155 .312,00$ & $32.387 .817 .921,00$ & $17.007 .635 .411,05$ \\
\hline \begin{tabular}{l} 
Iumlah \\
\hline
\end{tabular} & $77.180 .072 .899,00$ & $97.015 .501 .101,00$ & $190.294 .729 .768,00$ & $181.450 .080 .668,00$ & $172.707 .714 .618,72$ \\
\hline
\end{tabular}

(Sumber :dari Corporate Secretary Dompet Dhuafa)

Dari tabel tersebut, maka penerimaan dana Dompet Dhuafa cukup baik. walau dari total jumlah pertahun, terkadang naik-turun. Dana yang cukup meningkat adalah tahun 2010. Tetapi bila melihat jenis dana yang diberikan donator dana zakat merupakan dana yang terkumpul banyak dan meningkat ditiap tahunnya.

Kepercayaan merupakan tugas yang berat dilakukan lembaga, karena hal itu adalah untuk menjaga amanah masyarakat luas. Bahwa amanah merupakan sebuah rocta organisasi yang harus dijalankan, dijaga sebaik-baiknya dan kelak harus dipertanggungjawabkan kepada Sang Maha Pencipta. ${ }^{21}$

\section{B. Faktor Eksternal}

Pada penjelasan faktor eksternal ini, penulis berusaha menjelaskan transformasi Dompet Dhuafa dari luar lembaga Dompet Dhuafa. Pembahasan tersebut antara lain era Reformasi dan pengaruh yang cukup besar terhadap

${ }^{21} \overline{\text { Juwaini, Social Enterprise Transformasi Dompet }}$ Dhuafa, h. 244 perkembangan Dompet Dhuafa serta perkembangan Lembaga Amil Zakat di Indonesia pada umumnya. Pembahasan selanjutnya, adanya peristiwa bencana yang akan mendorong kebangkitan lembaga sosial-kemanusiaan di Indonesia.

\section{Reformasi dan Pengaruhnya Terhadap Perkembangan Lembaga Amil Zakat}

Lamanya kekuasaan rezim Orde Baru, yang berkuasa hampir 32 tahun banyak menimbulkan ketidakpuasan rakyat sehingga memunculkan Reformasi besar-besaran dalam segala aspek. Dompet Dhuafa yang berdiri pada akhir masa Orde Baru, dimasa Reformasi ini akan banyak menemukan perubahanperubahan baru dalam mengadapi tantangan di Era Reformasi. Tumbangnya rezim Orde Baru pada tahun 1998, akan mempengaruhi keadaan pada saat itu pula. Pada pembahasan ini, penulis membahas mengenai perkembangan zakat Indonesia (guna mengetahui perjalanan dan perkembangan lembaga zakat 
Indonesia) dan pengaruh dari adanya undang-undang zakat. Pembahasan ini merupakan faktor eksternal transformasi Dompet Dhuafa.

\section{a.) Perkembangan Zakat di Era Reformasi}

Sejarah perzakatan di Indonesia, sebenarnya sudah lama usaha dalam pengumpulan zakat ini. Pada era rezim Orde Lama (1950-1965) secara khusus belum ada yang dapat mengelola zakat secara besar dimasa Orde Lama tersebut. $^{22}$ Sekitar tahun 1950-an ada upaya melahirkan atau mengeluarkan peraturan-peraturan tentang zakat. Akan tetapi pada saat tersebut hasilnya belum mencapai puncak dan belum dapat menuai hasil yang membanggakan. ${ }^{23}$ Di tahun-tahun tersebut pengelolaan zakat di Indonesia, dapat dikatakan masih bersifat tradisonal, pengelolaan masih oleh orang-orang Masjid saja.

Tradisi pengelolaan zakat, yang terjadi pada masa era kemerdekaan sampai awal Orde Baru, yang terjadi hanya dalam suatu pola kelembagaan filantropi inter-personal, merata hampir di seluruh wilayah Indonesia. Kenyataan yang terjadi pada saat itu menunjukkan bahwa kelembagaan filantropi Islam dalam pandangan

\footnotetext{
${ }^{22}$ kondisi politik pada saat itu belum begitu stabil, pada saat itu masih dalam kepemerintahan Soekarno. Pada era tersebut, ada sebuah dukungan sebuah aktivitas filantropi dalam sebuah masyarakat modern. Kelompokkelompok Islamlah yang mana pada saat itu saling atau dapat dikatakan masih menyokong, ditandai dengan adanya sebuah aktivitas manajemen zakat, belum terpusat oleh negara. Lihat Amelia Fauzia, Faith and State: a History of Philantrophy in Indonesia, (Leiden, The Netherlands: Koninklijke Brill NV, 2013), h. 181

23 BAZIS DKI dan Institut Manajemen Zakat, Manajemen ZIS BAZIS Provinsi DKI Jakarta, (Jakarta: BAZIS DKI, 2006), h. 8
}

organisasi masih belum berkembang oleh masyarakat Islam. ${ }^{24}$

Pada masa pemerintahan Orde Baru, perhatian sebuah pemerintah terhadap pengelolaan zakat baru menguat. ${ }^{25}$ Disamping itu, pemerintah juga mendirikan Badan Amil Zakat (BAZ) sampai tingkat kecamatan. ${ }^{169}$ Pada tahun 1968, muncul beberapa pemikiran tentang perlunya Lembaga Pengelola Zakat (LPZ) di Indonesia. Pada tahun tersebut, ada sebelas tokoh ulama nasional yangmana menyerukan pelaksanaan zakat di Indonesia. Seruan tersebut, direspon dengan positif oleh Presiden RI saat itu. ${ }^{170}$

Perkembangan Lembaga Amil Zakat pada masa tersebut, belum terlalu begitu berkembang. Masih perlu sebuah pembelajaran dan sebuah pengalaman khusus untuk menjadi sebuah lembaga zakat yang profesional. Pada era tahun 90-an merupakan era Reformasi, awal pintu-pintu gerbang para lembaga zakat untuk berkiprah. Pada masa Reformasi lembaga zakat mengalami perkembangan yang cukup meningkat karena adanya perundangundangan di akhir Orde Baru, peraturan perundang-undangan zakat yang khusus mengelola tentang

24 yakni dimana filantropi zakat dikelola oleh kiai lokal atau modin, atau langsung diserahkan kepada para mustahik. Lihat dalam Amelia Fauzia dan Ary Hernawan, "Ketegangan antara Kekuasan dan Aspek Normatif Filantropi dalam Sejarah Islam di Indonesia", dalam Berderma untuk Semua : Wacana dan Praktik Filantropi Islam, (Jakarta: Pusat Bahasa dan Budaya UIN Jakarta, 2003), h.176-177

${ }^{25}$ Hal ini terbukti pada tanggal 15 juli 1968, pemerintah melalui Menteri Agama, mengeluarkan sebuah peraturan nomor 4 dan nomor 5 tahun 1968 tentang pembentukan Badan Amil zakat (BAZ) dan tentang pembentukan Baitul Mal (Balai Harta Kekayaan) di tingkat pusat, provinsi, dan juga kabupaten/kota. Lihat BAZIS DKI, Mengenal Hukum zakat dan Infak/ Sedekah, (Jakarta: BAZIS DKI, 1999), h. 16 
zakat.Dilanjutkan dengan keberadaan Lembaga Amil Zakat selain Dompet Dhuafa yang mulai bermunculan dimana-mana, setelah keluarnya Undang-Undang tentang pengelolaan zakat Nomor 38 Tahun 1999 tersebut $^{171}$.

Era Reformasi merupakan, perkembangan yang cukup baik bagi sejarah perkembangan zakat di Indonesia. Di era Reformasi ini, adanya Forum Zakat (FOZ). FOZ didirikan pada tahun 1997. Wadah ini bertujuan menampung aspirasi dan persoalan zakat dari para akivis praktisi zakat di Indonesia. ${ }^{26}$ Jumlah anggota awal dari FOZ ini cukup banyak. FOZ yang berdiri di era Reformasi ini akan banyak berperan khususnya memperjuangkan persoalan dalam pengelolaan zakat.

Di era Reformasi tersebut, Dompet Dhuafa juga terpengaruh dan mempengaruhi. Hal tersebut dibuktikan dengan keluarnya Undang-undang zakat Dompet Dhuafa termotivasi untuk dapat menjadi LAZ di tingkat Nasional, dan Dompet Dhuafa juga mempengaruhi LAZ lain sehingga LAZ bermunculan dimana-mana. Kemunculan FOZ (forum zakat), dimana Dompet Dhuafa menjadi pendorong forum tersebut. Forum ini merupakan wadah menampung aspirasi dan persoalan zakat. Kemunculan FOZ ini sangat berpengaruh terutama dalam perkembangan zakat di Indonesia.

\section{b.) Pengaruh Undang-Undang Zakat}

\footnotetext{
26 Dengan keluarnya Undang-Undang tentang pengelolaan zakat Nomor 38 Tahun 1999 merupakan perkembangan yang cukup baik bagi lembaga zakat Indonesia. Dengan adanya undang-undang tersebut di harapkan amil zakat di Indonesia dapat mengelola zakat secara produktif dan optimal. lihat Uswatun Hasanah, "Potret Filantropi Islam, Di Indonesia", lihat dalam Idris Thaha, Ed., Berderma Untuk Semua Wacana dan Praktik Filantropi Islam, (Jakarta: Pusat Bahasa dan Budaya UIN Jakarta dan Teraju, 2003), h. 218
}

Pada tahun 1998, ada seorang ulama besar dari Mesir Yusuf Qardhawi yang hadir di Indonesia, di daerah Kemang-Jakarta. Dalam hal ini, ada sebuah acara dialog terbuka di Insitut Bank Indonesia. Dalam acara tersebut berbagai pertanyaan dan juga sebuah diskusi interaktif berlangsung dengannya, tentunya dipandu oleh M. Syafi'i Antonio dan Anis Matta. ${ }^{27}$ Adanya diskusi dalam acara tersebut memberikan perubahan bagi dunia zakat Indonesia, zakat tentu saja boleh didirikan oleh pemerintah karena memang itu haknya, sedangkan masyarakat melalui lembaga didirikan juga bisa melakukannya.

Seiring dengan berjalannya waktu, banyak pihak yang mana dengan serius menanggapi persoalan sebuah zakat. Hal ini dapat terlihat dari sekian banyaknya jabaran atau sebuah proses perundang-undangan mengenai pengelolaan zakat dan berakhir dengan ditetapkannya undang-undang nomor 38 tahun 1999 sebagai undang-undang baku mengenai pengelolaan zakat.

Rancangan Undang-undang tentang perzakatan itu disahkan oleh DPR pada September 1999. Salah satu pengaruh yang cukup positif dalam undang-undang itu adalah eksistensi kedudukan lembaga zakat yang tumbuh atas inisiatif masyarakat diakui dan dilegalkan keberadaannya. Lembaga zakat masyarakat dalam Undang-undang

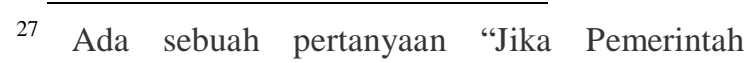
Indonesia sedang mengalami problem besar sehingga tidak konsentrasi mengelola zakat, sementara masyarakat juga belum bisa percaya kepada pemerintah, apakah boleh masyarakat mengelola dana zakat tersebut?" selanjutnya Yusuf Qardhawi menjawab dengan amat singkat; "Jika kondisi nya memang begitu, boleh. Zakat boleh dikelola oleh masyarakat." Dengan adanya jawaban tersebut membuat lega masyarakat, dikarenakan adanya sebuah pembaharuan akan diskusi tersebut, terlebih yang menyampaikan adalah Ulama Dunia yang rujukannya dipakai pengelolaan zakat di seluruh negara. Lihat dalam Sudewo, Manajemen Zakat, h. 24 
disebut sebagai Lembaga Amil Zakat (LAZ). Sedangkan lembaga yang didirikan oleh pemerintah dinamakan Badan Amil Zakat (BAZ). ${ }^{28}$

Dengan berpegang pada undangundang nomor 38 tahun 1999, baik pembentukan Badan Amil Zakat (BAZ) maupun Lembaga Amil Zakat (LAZ) manajemen keduanya tetap mengikat pada pola manajemen pemerintah yang telah dibuat. Undang-undang tersebut merupakan proses perubahan dari beberapa peraturan sebelumnya, sekaligus sebagai beberapa tambahan pelengkap untuk penyempurnaan. Jadi lahirnya undang-undang nomor 38 tahun 1999 mengenai pengelolaan zakat bertujuan untuk mengefektifkan pengelolaan zakat di Indonesia agar lebih maju dan profesional terhadap kondisi yang ada sebelumnya.

Undang-Undang

yang

dikeluarkan pemerintah menimbulkan banyak pengaruh positif bagi kalangan umat Islam. Dahulu pengelolaan zakat yang dapat dikatakan masih tradisional dengan mengandalkan masjid, pesantren sebagai tempat yang selalu mengurusi zakat, kini sudah ada lembaga atau tempat khusus untuk dapat mengatur,mengelola serta mendistribusikan zakat tersebut.

Babak baru perkembangan dalam dunia filantropi Islam (Lembaga Zakat), terjadi pada saat krisis ekonomi (termasuk bencana alam) yang terjadi di Indonesia. Kejadian tersebut terjadi pada masa Reformasi tahun 1998. Krisis ekonomi yang merupakan keadaan yang sangat panas bagi semua orang, dimana membakarnya semangat komunitas muslim guna mengatasi problem krisis tersebut. Kenyataan itu, dimulai dari Yayasan Dompet Dhuafa Republika yang dibentuk oleh karyawan Republika merespon bencana kelaparan yang hebat

\footnotetext{
${ }^{28}$ Sudewo, Manajemen Zakat, h. 25
}

di gunung Kidul, Yogyakarta. Demikian juga dengan Pos Keadilan Peduli Ummat (PKPU) yang merespon bencana alam. Selain itu ada lembaga filantropi Islam lain seperti Dompet Sosial Ummul Quro' (DSUQ), Yayasan Dana Sosial Al Falah (YDSF), Yayasan Daarul Tauhid dan lain-lainnya. Jadi suatu fenomena yang cukup baik tumbuhnya organisasi filantropi Islam di Indonesia, dengan berbasis masyarakat disebut dengan sebutan Lembaga Amil Zakat, Infak dan Sedekah (LAZIS), Reformasi menandai akan babak baru dalam sebuah pengelolaan filantropi Islam di Indonesia. ${ }^{29}$

\section{Kebangkitan Lembaga Sosial- Kemanusiaan Akibat Peristiwa Bencana Indonesia}

Indonesia merupakan salah satu negara yang merupakan negara rawan bencana. Di Indonesia tidak hanya satu jenis bencana saja yang terjadi, melainkan lebih dari satu jenis bencana yang timbul di permukaan tanah air Indonesia, dampaknya tidak sedikit yang mengalami kehilangan harta benda, kerugian, serta tak luput banyak mengambil korban jiwa.

Dalam pembahasan ini, penulis menjelaskan bahwa kebangkitan lembaga sosial-kemanusiaan akan banyak bermunculan di saat atau setelah peristiwa bencana alam di Indonesia. Peristiwa tersebut, penulis cantumkan ke dalam faktor eksternal transformasi Dompet Dhuafa.Bencana Alam yang datang tidak terencana, sudah banyak sekali menimpa negeri ini. Bencana yang terbesar dalam beberapa tahun terakhir adalah peristiwaTsunami di Daerah Istimewa Aceh dan Sumatera Utara

29 Ridwan Al Makassary, "Pengarustamaan filantropi Islam untuk Keadilan Sosial di Indonesia: proyek belum selesai" Galang Jurnal Filantropi dan Masyarakat Madani Vol. 1, no. 3, (PIRAC, April 2006). h. 42 
pada tanggal 26 Desember 2004 yang kemudian disusul oleh gempa bumi di Daerah Istimewa Yogyakarta dan Jawa Tengah pada tanggal 27 Mei 2006 yang lalu. ${ }^{30}$

Dalam peristiwa Bencana terbesar, tidak sedikit media yang meliput kejadian, aktivitas di bencana bahkan berita-berita terbaru mengenai bencana tersebut. Mulai dari media penyiaran, media cetak, atau sejumlah gabungan perusahaan ikut turut membantu dalam mengatasi penanggulangan bencana tersebut. Sejumlah perusahaan media pada saat itu, banyak yang melakukan kerja sama dengan organisasi dan LSM lainnya misalnya saja Palang Merah Indonesia, Pemerintah Lokal, Satkorlak PBP dan organisasi-organisasi keagamaan, begitu pula beberapa yayasan filantropi lainnya seperti Dompet dhuafa, MER$\mathrm{C}$ (Medical Emergency Rescue Committe). ${ }^{31}$

Bencana di Daerah Istimewa Aceh tersebut merupakan salah satu jenis bencana nasional Indonesia, hampir semua kepala organisasi atau orang lain banyak turut terjun dalam penanganan bencana ini. Selain dari lembaga yang berasal dari Indonesia, ada pula sebuah lembaga luar negeri yang turut membantu dalam penanganan bencana ini salah satunya adalah komponen gerakan Internasional Palang Merah dan Bulan Sabit Merah, yang mana dalam hal ini adalah ICRC $^{181}$ (International Committee of The Red Cross) dan IFRC ${ }^{182}$ (International Federation of Red Cross) yakni suatu organisasi Internasional yang banyak

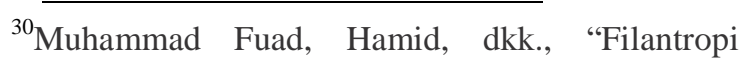
Media dan Bencana di Indonesia”, lihat Galang, Jurnal Filantropi dan Masyarakat Madani .Vol. 2, No. 1, (PIRAC, Oktober 2006), h. 5

${ }^{31}$ Muhammad Fuad, Hamid, dkk., "Filantropi Media dan Bencana di Indonesia", lihat Galang, Jurnal Filantropi dan Masyarakat Madani . h. 5 terjun dalam mengatasi permasalahan kemanusiaan di dunia.

Bencana kemanusiaan yang beraneka ragam tersebut, apapun bentuknya pada akhirnya membuat orang yang terkena bencana menjadi penyebab bertambahnya orang miskin sesaat atau orang miskin berkelanjutan akibat penanganan bencana yang tidak baik tentunya. Hal tersebut tentunya harus mendapat perhatian pula dari seluruh lembaga zakat, mengingat kemiskinan dapat meliputi hampir kebutuhan dasar hidupnya mengalami banyak kekurangan. Lembaga zakat tersebut juga ikut turut melakukan penanganan yang serius terhadap bencana kemanusiaan. ${ }^{32}$

Peristiwa Bencana besar yang terjadi di Daerah Istimewa Aceh telah banyak merubah lembaga sosialkemanusiaan atau LSM lainnya. Kesadaran akan daerah rawan bencana tersebut menimbulkan sebuah kebangkitan bagi lembaga- lembaga sosial-kemanusian. Selain itu, yayasan atau lembaga filantopi yang dahulu belum begitu banyak, kini muncul dengan tujuan bersama-sama untuk mengumpulkan galangan dana bagi daerah yang terkena bencana alam.

Perkembangan Dompet Dhuafa semakin lama semakin meningkat secara perlahan. Dalam penganalisaan penulis, suatu transfornasi (perubahan) yang terjadi dalam Dompet Dhuafa merupakan suatu proses yang berkembang dengan waktu yang cukup panjang, secara perlahan-lahan dan setahap demi tahap, perubahan tersebut cukup terjadi dan terbukti secara nyata. Dengan melihat transformasi dari sisi faktor eksternal, yakni era Reformasi dan juga

\footnotetext{
${ }^{32}$ Surahman Hidayat, "Peranan Institusi Zakat Dalam Penanganan Bencana Kemanusiaan di Indonesia" lihat dalam M. Arifin Purwakanta, Noor Aflah, Southeast Asia Zakat Movement,(Jakarta: Forum Zakat dan Pemkot Padang, 2008), h. 265
} 
pengaruhnya terhadap lembaga zakat terutama Dompet Dhuafa, dari pengaruh tersebut mempunyai dampak adanya suatu peraturan perundang-undangan zakat yang baik tentunya dalam memantapkan kedudukan lembaga zakat di Indonesia. Disamping itu, peristiwa bencana di Indonesia yang terjadi pada tahun 2004 menjadikan suatu dorongan kebangkitan lembaga sosial-kemanusiaan khususnya untuk dapat semakin peduli dan tanggap terhadap bencana dan kepada yang membutuhkan bantuan.

Selain faktor tersebut, ada faktor lain yang cukup mempengaruhi yaitu pada masa akhir era Orde Baru adanya perkembangan umat Islam di Indonesia. Diawali dengan kelahiran ICMI, adanya kesadaran gairah umat Islam untuk melaksanakan ajaran agama dengan lebih baik dan intens. Pada masa itu juga lahir Republika dan Bank Muamalat, dan selanjutnya baru Dompet Dhuafa. ${ }^{33}$ Melihat dari sisi eksternal, transformasi Dompet Dhuafa begitu banyak yang mempengaruhi perkembangan Dompet Dhuafa.

Selanjutnya dari sisi faktor internal Dompet Dhuafa, transformasi Dompet Dhuafa terlihat jelas dengan adanya struktur dan program-program inovasi yang semakin bertambah dan juga perubahan yang cukup, adanya suatu rencana strategis yang matang dan juga indikator keberhasilan yang dijadikan sebagai tolak ukur lembaga. Akan tetapi, yang utama adalah kualitas sumber daya manusia yang professional, adanya dukungan donatur yang cukup baik, nilai semangat Islami yang tinggi, yang ada pada orang-orang yang bekerja di Dompet Dhuafa.

Dengan melihat kedua sisi faktor tersebut, suatu tranformasi (perubahan) Dompet Dhuafa terjadi dengan bagitu

\footnotetext{
${ }^{33}$ Wawancara dengan Bapak Ahmad Juwaini (Presiden Direktur Dompet Dhuafa), 9 Oktober 2013
}

baik, secara perlahan-lahan dan tidak mengalami perubah secara cepat dan signifikan. Dahulu Dompet Dhuafa yang merupakan Yayasan yang masih bersifat tradisional selanjutnya menjadi Lembaga Amil Zakat tingkat nasional, pengelolaan zakatpun berbeda dari sebelumnya. Era Reformasi melahirkan peraturan perundang-undangan zakat, sehingga kini semakin mewujudkan perubahan yang cukup baik dalam perkembangan lembaga zakat di Indonesia dan khususnya Dompet Dhuafa.

Jenis program yang semakin berinovasi dan berkembang mengarahkan aktivitas Dompet Dhuafa bukan hanya bergerak dalam lingkup ZISWAF saja, berbeda dengan LAZ lainnya. Dompet Dhuafa juga bergerak dalam lingkup program sosial-kemanusiaan, terbukti dari analisa transformasi yang didapat. Di tambah dengan adanya keinginan menjadi World Class organization, menjadikan Dompet Dhuafa menjalankan aktivitasnya bukan hanya di Indonesia tetapi di mancanegara, dengan ikut berperan aktif dalam membantu masyarakat khususnya yang membutuhkan bantuan.

\section{Penutup}

\section{A. Kesimpulan}

Aspek penting perkembangan Dompet Dhuafa ini terbagi menjadi periode perintisan awal Dompet Dhuafa (1993-1998), periode transisi Dompet dhuafa (1999-2003), dan periode sosialkemanusiaan Dompet Dhuafa (20042012). Studi penelitian ini membuktikan bahwa Dompet Dhuafa berkembang bukan hanya sebagai lembaga zakat, dan semakin berkembang menjadi lembaga sosial- kemanusiaan.

Dampak dari keterlibatan karyawan Dompet Dhuafa Republika dalam kepedulian pengumpulan dana, 
telah banyak meluas. Berawal dari Gunung kidul sampai menuju skala nasional. Pengumpulan dana tersebut, berkat adanya publikasi yang cukup efektif melalui media harian Republika. Dompet Dhuafa bukan hanya menjalankan tugas pada bantuan dana bagi kalangan dhuafa saja, tetapi nantinya akan semakin berkembang dalam bentuk program seperti bantuan ekonomi, kesehatan, sosial, dan bantuan kemanusiaan.

Transformasi yang terjadi pada Dompet Dhuafa merupakan perubahan yang cukup baik dan menunjukkan sebuah peningkatan di setiap tahunnya. Transformasi yang terjadi tersebut merupakan suatu perubahan yang dilakukan dengan secara bertahap, dan terencana dengan baik. Transformasi ini dimungkinkan karena adanya faktor internal dan faktor eksternal. Faktor internal (dalam) Dompet Dhuafa memberikan suatu hasil yang cukup baik yaitu dengan adanya nilai semangat Islami, yakni adanya semangat rasa peduli seperti yang di ajarkan agama untuk dapat saling berbagi dan membantu sesama. Sumber daya manusia yang berkualitas, merupakan suatu pendukung dengan adanya SDM yang baik guna memberikan ide serta keahlian khusus sehinggaDompet Dhuafa dapat menghasilkan program inovasi. Kemudian, adanya dukungan donatur yang cukup baik, yang merupakan jalinan komunikasi yang baik dan menumbuhkan kepercayaan. Selanjutnya, perkembangan struktur dan program-program Dompet Dhuafa disetiap periode atau tahunnya berubah sesuai dengan kebutuhan lembaga dan juga masyarakat. Selain dari faktor internal, ada pula faktor eksternal yang mempengaruhi transformasi Dompet Dhuafa,

Faktor eksternal merupakan
faktor luar yang mempengaruhi
perkembangan Dompet Dhuafa. Faktor

eksternal yang menjadi pengaruh Dompet Dhuafa berkembang adalah keluarnya Undang-undangan yang membahas khusus mengenai zakat di tahun 1999 pada era Reformasi. Dampak Undangundang tersebut menjadikan hal positif bagi perkembangan Dompet Dhuafa dan terlebih perkembangan zakat diIndonesia pada umumnya. Selanjutnya ada lagi, kebangkitan lembaga sosialkemanusiaan. Peristiwa tsunami yang terjadi pada tahun 2004 di Aceh, membangkitkan hampir sebagian besar lembaga sosial- kemanusiaan Indonesia, kejadian tersebut memberikan suatu dorongan untuk saling peduli dan tumbuhnya semangat sosial-kemanusiaan dengan menyumbangkan dana.

Transformasi yang terjadi pada program dan juga struktur Dompet Dhuafa merupakan perubahan yang terjadi secara perlahan-lahan. Programprogram Dompet Dhuafa jumlahnya cukup banyak dan memberikan manfaat yang cukup bagi masyarakat luas. Semakin meningkatnya kualitas sumber daya manusia memunculkan suatu ide dalam program lembaga. Program inovasi yang timbul tersebut mengakibatkan beraneka ragamnya program Dompet Dhuafa. Adapun program dahulu Dompet Dhuafa adalah penghimpunan zakat, dengan perubahan dari inovasi tersebut program Dompet Dhuafa berupa program pemberdayaan masyarakat, program sosial-kemanusiaan. Hal ini menandai bahwa kini Dompet Dhuafa bukan hanya sebagai lembaga amil zakat saja, tetapi telah menjadi lembaga sosial-kemanusiaan.

Transformasi (perubahan) yang terjadi Dompet Dhuafa merupakan suatu perubahan yang terjadi secara terusmenerus dan secara bertahap. Dari Lembaga Amil Zakat menjadi Lembaga Sosial-kemanusiaan tidak mudah untuk dapat menjalankannnya. Pengaruh dari Reformasi memunculkan sebuah 
keuntungan yang cukup besar bagi lembaga zakat dan juga Dompet Dhuafa. Dari pengaruh tersebut, Dompet Dhuafa mulai bergerak memunculkan ide, inovasi program- programnya dan mengembangkan jejaring kerjasama dengan lembaga lain.

\section{B. Saran}

Setelah melakukan studi penelitian ini, pembahasan atau kajian penelitian mengenai lembaga atau organisasi filantropi Islam di Indonesia masih sangat terbatasTerlebih kini kita ketahui, perkembangan filantropi Islam di Indonesia semakin berkembang dan banyak bermunculan dimana-mana.

Penulis menghendaki dan menyarankan bahwa penelitan studi ini masih sangat terbatas, maka hendaknya peneliti baru yang ingin meneliti untuk dapat menjadi kajian penelitian khususnya perkembangan filantropi Islam dan lembaga filantropi Islam di Indonesia. Selain itu, disarankan kepada perpustakaan Adab dan Humaniora dan perpustakaan Utama UIN Syarif Hidayatullah untuk dapat melengkapi koleksi tulisan-tulisan sejarah perkembangan filantropi Islam dan juga perkembangan lembaga filantopi yang terbaru khususnya mengenai Dompet Dhuafa Republika atau organisasiorganisasi penghimpun zakat.

\section{Daftar Pustaka}

\section{Sumber Tertulis}

\section{a. Buku}

Abubakar, Irfan dan Bamualim, Chaider S., ed., Filantropi Islam dan Keadilan Sosial Studi tentang Potensi, Tradisi, dan pemanfaatan Filantropi Islam di Indonesia. Jakarta : CSRC UIN Jakarta, 2006.
Abubakar, Irfan dan Bamualim, Chaider S. ed., Revitalisasi Filantropi Islam Studi Kasus Lembaga Zakat dan Wakaf Di Indonesia. Jakarta: Pusat Bahasa dan Budaya UIN Jakarta, 2005

Ali, Mohammad Daud. Lembagalembaga Islam di Indonesia. Jakarta: PT Raja

Grafindo Persada, 1995.

Abdurrahman, Dudung. Metode Penelitian Sejarah. Jakarta: Logos Wacana Ilmu, 1999.

Anwar, M. Syafi'i. Pemikiran dan Aksi Islam Indonesia Sebuah Kajian Politik

Tentang Cendekiawan Muslim Orde Baru. Jakarta, Paramadina, 1995.

BAZIS DKI dan Institut Manajemen Zakat, Manajemen ZIS BAZIS Provinsi DKI Jakarta. Jakarta: BAZIS DKI, 2006.

Departemen Agama RI , Petunjuk Pelaksanaan Akreditasi Organisasi Pengelola Zakat, Jakarta: Direktorat Pemberdayaan Zakat Departemen Agama RI,2007.

Fauzia, Amelia. Faith and State: a History of Philantrophy in Indonesia. Leiden, The Netherlands: Koninklijke Brill NV, 2013.

Gottschalk, Louis. Mengerti Sejarah, terj. Nugroho Notosusanto. Jakarta:UI Press, 1983.

Juwaini, Ahmad. Social Enterprise Transformasi Dompet Dhuafa Menjadi World Class Organization. Cet. 1. Jakarta: Expose (Mizan Group) Anggota IKAPI, 2011.

Kuntowijoyo, Metodologi Sejarah. Yogyakarta: PT Tiara Wacana, 2003. 
Koentjaraningrat, ed., Metode-Metode

Penelitian Masyarakat. Jakarta:

Gramedia,

1979.

Kuntowijoyo. Pengantar Ilmu Sejarah.

Yogyakarta: Bentang Pustaka, 2005.

Muallidin, Isnaini. "Pergulatan Cendekiawan Muslim di Bawah negara Orde Baru: Potret Keberadaan ICMI" dalam Qodir, Zuli dan Songell, M. Iqbal ed., ICMI, Negara dan Demokratisasi, cet I. Yogyakarta: Kelompok Studi Lingkaran, 1995.

Noer, Deliar. Gerakan Modern Islam di Indonesia 1900-1942. Jakarta :LP3ES. Pranoto, Suhartono W. Teori dan metodologi Sejarah, cet. I . Yogyakarta: Grahallmu, 2010.

Purwakananta, M. Arifin, Aflah, Noor, Southeast Asia Zakat Movement, Jakarta: Forum Zakat dan Pemkot Padang, 2008

Purwakananta, M. Arifin, dkk. Peta Kemiskinan Data Mustahik, Muzaki dan Potensi Pemberdayaan Indonesia. Jakarta: Dompet Dhuafa. 2010.

Reksaningtyas, dkk., Manual Kepalangmerahan. Jakarta: Palang Merah

Indonesia, 2009.

Rukhiyat, Adang dkk., Panduan Penelitian Bagi Remaja, Cet. III . Jakarta CV.

Tumaritis, 2003.

Razak, Nasruddin. Dinnul Islam: penafsiran kembali islam Sebagai suatu akidah dan way of life. Bandung: Al Ma'arif, 1989.
Reksaningtyas , Aswi, dkk., Manual Kepalangmerahan, Jakarta: Palang Merah

Indonesia, 2009.

Soekanto, Soerjono. Sosiologi Suatu pengantar, Jakarta:Rajawali Press, 2012

Sudewo, Eri. Manajemen Zakat Tinggalkan 15 Tradisi Terapkan 4 Prinsip

Dasar. Cet I. Jakarta: Institut Manajemen Zakat, 2004.

Sztompka, Piotr, Sosiologi Perubahan Sosial, Edisi I, cet ke 3, Jakarta: Prenada,

2000

Thaha, Idris Ed., Pedoman penulisan Karya Ilmiah (Skripsi, Tesis dan Disertasi.

Cet 1. Jakarta: CeQDA UIN Syarif Hidayatulla Jakarta, 2007.

Thaha, Idris ed., Berderma Untuk Semua Wacana Filantropi dan Praktik filantropi Islam. Jakarta: Pusat Bahasa Dan Budaya UIN Jakarta, 2003.

\section{b. Arsip, Dokumen, Jurnal, Skripsi}

Annual Report Dompet Dhuafa tahun 2002

Annual Report Dompet Dhuafa tahun 2003

Annual Report Dompet Dhuafa tahun 2004

Annual Report Dompet Dhuafa tahun 2008

Annual Report Dompet Dhuafa tahun 2010

Dompet Dhuafa Menuju Millenium III

Al Makassary, Ridwan, "Pengarustamaan filantropi Islam untuk Keadilan Sosial di Indonesia: proyek belum selesai" 
Galang Jurnal Filantropi dan http://nasional.kompas.com/read/2010/06/0 Masyarakat Madani Vol. 1, no. 3, 7/14111723/Dompet.Dhuafa.Akan.Ba PIRAC, April 2006. ngun.Sumur.di.Gaza

Razak, Ridwan. "Pengarustamaan Yurnaldi, "Diluncurkan, Program filantropi Islam untuk Keadilan Sosial di Indonesia: proyek belum selesai" Galang Jurnal Filantropi dan Masyarakat Madani Vol. 1, No. 3, PIRAC , April 2006

Sedekah Pohon", KOMPAS, Minggu, 14

Februari 2010 | 17:24 WIB. Artikel diakses pada 20 Mei 2013, Lihat dalam http://nasional.kompas.com/read/2010/ 02/14/17244496/Diluncurkan..Prog

Fuad, Muhammad, dan Hamid, dkk., "Filantropi Media dan Bencana di Indonesia", lihat Galang, Jurnal Filantropi dan Masyarakat Madani .Vol.

2, No. 1, PIRAC , Oktober 2006.

\section{c. Internet}

Antony Lee, "Ada Rumah Sehat Gratis di Jalan Parung", Kompas, Kamis, 20

Oktober 2011 | 08:58 WIB Editor :Robert Adhi, artikel diakses pada 20

Mei 2013,

Hertanto Soebijoto . Ed., "Dompet Dhuafa Akan Bangun Sumur di Gaza", ram.Sedekah.Pohon

Dompet Dhuafa, "Visi dan Misi", artikel diakses pada 5 Mei 2013 dari http://www.dompetdhuafa.org/profil/vi $\underline{\text { si-misi/ }}$

Dompet Dhuafa, "Sejarah", artikel diakses pada 5 Mei 2013 dari http://www.dompetdhuafa.org/profil/sejara $\underline{\mathrm{h} /}$

\section{Sumber Lisan}

a. Wawancara

Wawancara dengan Bapak M. sabet Abilawa (GM Corporate secretary), 21 Mei 2013

Wawancara dengan Bapak Gerald Reza lasut ( Kepala Markas PMI Tangsel), 14 Mei 2013 